\title{
Payment for Ecosystem Services in China: An Overview
}

\author{
Lin Zhen \\ Institute of Geographic Sciences and Natural Resources Research \\ Chinese Academy of Sciences, \\ 11A Datun Road, Chaoyang District, \\ Beijing 100101, PR China \\ email: zhenl@igsnrr.ac.cn \\ Huiyuan Zhang \\ Chinese Academy for Environmental Planning, \\ Dayangfang, Beiyuan Road, Chaoyang District, \\ Beijing 100012, PR China \\ email: zhanghy@caep.org.cn
}

Accepted on 9 June 2011

Published on 22 June 2011

\begin{abstract}
To address the multiplying conservation challenges and resource constraints in face of breakneck economic growth, policymakers in China have become increasingly interested in developing new approaches in environmental policy. For this reason, Payment for Ecosystem Services (PES) is becoming a topic of discussion in society. This paper provides a general review of PES in China from both a theoretical and a practical perspective. It starts with an outline of relevant terms used by the international community, and is followed by a discussion of major components covered in PES for implementation, including basic principles, methods to determine compensation standards and approaches. The main PES programmes that have been implemented are presented. The paper reveals that PES in China has unique characteristics, compared to other countries, and that the necessary policy frameworks for developing PES and purely market-based instruments in China are rapidly taking shape. However, to successfully implement PES, the relations and conflicts between central government and local governments, between the government and the market, and between PES and poverty alleviation must be taken into consideration.
\end{abstract}

Keywords: ecosystem services, PES in China, PES programs, compensation

This review is licensed under a Creative Commons Attribution-Non-Commercial-NoDerivs 3.0 Germany License. http://creativecommons.org/licenses/by-nc-nd/3.0/de/ 


\section{Imprint / Terms of Use}

Living Reviews in Landscape Research is a peer reviewed open access journal published by the Leibniz Centre for Agricultural Landscape Research (ZALF), Eberswalder Straße 84, 15374 Müncheberg, Germany. ISSN 1863-7329.

This review is licensed under a Creative Commons Attribution-Non-Commercial-NoDerivs 3.0 Germany License: http://creativecommons.org/licenses/by-nc-nd/3.0/de/

Because a Living Reviews article can evolve over time, we recommend to cite the article as follows:

Lin Zhen and Huiyuan Zhang,

"Payment for Ecosystem Services in China: An Overview",

Living Rev. Landscape Res., 5, (2011), 2. [Online Article]: cited [<date >], http://www.livingreviews.org/lrlr-2011-2

The date given as $<$ date $>$ then uniquely identifies the version of the article you are referring to.

\section{Article Revisions}

Living Reviews supports two ways of keeping its articles up-to-date:

Fast-track revision A fast-track revision provides the author with the opportunity to add short notices of current research results, trends and developments, or important publications to the article. A fast-track revision is refereed by the responsible subject editor. If an article has undergone a fast-track revision, a summary of changes will be listed here.

Major update A major update will include substantial changes and additions and is subject to full external refereeing. It is published with a new publication number.

For detailed documentation of an article's evolution, please refer to the history document of the article's online version at http: //www.livingreviews.org/lrlr-2011-2. 


\section{Contents}

1 Introduction $\quad 5$

2 Terms relevant to Payment for Ecosystem Services $\quad 6$

3 Major components of PES schemes in China $\quad \mathbf{8}$

3.1 Basic financial principles for PES schemes . . . . . . . . . . . . . . . . 8

3.2 Determination of compensation standards . . . . . . . . . . . . . . . . . . . 9

3.3 Approach for PES . . . . . . . . . . . . . . . . . . . 10

4 The rapid rise of PES in China $\quad 11$

4.1 Major PES programmes in China . . . . . . . . . . . . . . . . . . . 11

4.2 Pilot studies on PES implementation in China . . . . . . . . . . . . . . . 16

$\begin{array}{llr}5 & \text { Future perspectives } & 18\end{array}$

$\begin{array}{llr}6 & \text { Acknowledgements } & 18\end{array}$

$\begin{array}{lr}\text { References } & 19\end{array}$

\section{List of Tables}

1 Ecosystem services and their constituents . . . . . . . . . . . . . . . . . . 8

2 Major PES programmes in China . . . . . . . . . . . . . . . . . . 11

3 Findings from the pilot study in selected key fields for PES in China. . . . . . . . . 17 



\section{Introduction}

Due to the rapid development of China's economy, ecological and environmental problems have increasingly become bottlenecks, restricting the overall sustainability of the country's socio-economic development. The Chinese government has proposed a concept of scientific development with an emphasis on people-centred, integrated, coordinated and sustainable development. Special attention has been placed on ecological construction through various policies and means, which has contributed significantly to the improvement of ecological conditions in China. However, policies related to ecological conservation are not readily in place. In particular, economic policies for ecological construction are still lacking, leading to an unequal distribution of ecological benefit and economic benefit between protectors and beneficiaries, polluters and victims. Consequently, beneficiaries are gaining from ecological benefit without bearing the responsibilities and costs of deteriorating the ecosystem, whereas the protectors are not being offered the necessary economic incentives. In China, both purely public goods and the common pool of resources have the common issue of externality generated in the process of supply and consumption. Most ecosystem services are public goods (MEA, 2003) and rivalrous in consumption. For this reason, PES from the government is required to internalise the externality caused by consumption activities ( $\mathrm{Yu}$ and Ren, 2007). Externality is divided into positive externality (external economical) and negative externality (external uneconomical). Positive externality refers to the fact that the production or consumption of some economic entity benefits other economic main bodies, albeit without gaining compensation from the latter, such as ecosystem conservation in nature reserves and upper reaches of river basins. Negative externality refers to the fact that the production or consumption of some economic entity damages other economic main bodies, albeit without providing compensation to the latter, such as environmental pollution by enterprises and the eco-environmental destruction caused in the process of mineral resources development. Negative externality also involves the damaging economic agent not incorporating the negative external costs into his economic decisionmaking. With respect to ecosystem services (ES) and PES, this implies the consumption of ES at unsustainable levels. As to the internalisation of externality, there are three different approaches in the economic circle: "Pigovian Tax", Coase's "Ownership" and PES (Pigou, 1932; CCICED, 2007).

The unique feature of most ecosystem services is that they are unaccounted for and unpriced, and therefore remain outside the domain of the market. Against this national backdrop, policymakers in China have become increasingly interested in developing new approaches in environmental policy to address the country's multiplying conservation challenges and resource constraints (Zhang et al., 2010). This includes a growing number of programmes that are increasingly utilising Payments for Ecosystem Services (PES) schemes, in line with international trends towards applying PES primarily as a way to improve economic efficiency through market-based instruments to internalise environmental externalities (Engel et al., 2008; Pagiola and Platais, 2007). The Chinese government has made the development of "PES schemes" a priority. The State Council release no. 39 [2005] entitled State Council Decision Regarding Using the Scientific Development View to Strengthen Environmental Protection states that the government "... should improve PES policy, and develop PES schemes as quickly as possible," (State Council, 2005, Section 23, sentence 7). China's 11th Five-year Guidelines (2006-2010) call for innovation in environmental policy, and the development of PES pilots, and for policy-makers to quicken the pace of development of PES schemes, to develop intra-regional and watershed-related PES schemes, and to resolve funding issues regarding conservation. In response to the 11th Five-year Guidelines, China's Ministry of Environmental Protection (MEP) issued Guiding Opinions on the Development of Eco-compensation Pilot Work (MEP, 2007), and set up prioritised fields for implementing PES.

This paper aims to review PES programmes in China. It starts with an introduction to the terms relevant to PES amongst scientific communities and decision-makers across the globe. This 
is followed by general principles used in PES and a discussion of the major PES programmes that have been implemented in China, as well as future perspectives concerning PES. This paper will provide a basis for the scientific community to carry out further PES research and for policy-makers to review and improve their decision-making processes on the basis of previous experiences and lessons made.

\section{Terms relevant to Payment for Ecosystem Services}

Ecologists, environmentalists, social scientists, policy-makers, community leaders and others have used various terms to describe market-based instruments that reward the stewardship of ecosystem services benefiting "external" actors. When such programmes initially attracted significant attention in the 1990s, the predominant name was payment for environmental services. In recent years, however, critics have challenged both the payments and environmental components of this nomenclature (Engel et al., 2008; Bennett, 2009). From an ecosystem point of view, ecosystems provide services that sustain, strengthen, and enrich various constituents of human well-being (Kumar and Muradian, 2009). To maintain a healthy ecosystem and, at the same time, to meet the basic requirements of human well-being, scientists have started studying payment for ecosystem services, which is often abbreviated to PES. Terms relevant to PES are as follows:

Ecosystem Services (ES): ES are the benefits people gain from ecosystems to sustain human well-being (MEA, 2003; Kumar and Muradian, 2009). These include provisioning services such as food and water; regulating services such as the regulation of floods, drought, land degradation and disease; supporting services such as soil formation and nutrient cycling; and cultural services such as recreational, spiritual, religious and other non-material benefits (Table 1). With regard to PES, all of these ES are taken into consideration.

Payment for Ecosystem Services (PES): PES is a type of market-based environmental policy instrument. Some of these instruments incorporate, to varying degrees, aspects of marketbased approaches (Sterner, 2003). They can be essentially defined in terms of payments to land managers and others to undertake actions that increase the quantity and quality of desired ecosystem services, which benefit specific or general users, often remotely. PES, effectively, provide incentives to address market failure by altering the economic incentives faced by land managers or others who can affect the delivery of ecosystem services (CCICED, 2007). In this sense, it can be argued that PES fits within the broad category of market-based (economic) instruments that include taxes and charges, subsidies and tradable permits (DEFRA, 2010). PES is defined as a transaction between providers and beneficiaries of ecosystem services, using innovative instruments to manage and measure transactions between providers and beneficiaries of ecosystem services (Kumar and Muradian, 2009). PES has emerged as one of the most innovative and cost-effective responses to the management of ecosystem services. Payments have been successfully designed and executed for carbon, watershed services, genetic material and various other nutrients.

The basic idea behind PES schemes is that the users/beneficiaries of a service compensate the providers. Beyond this, PES can vary according to a number of characteristics, including:

- Provision of ecosystem services, which can be based on one specific service (e.g. carbon sequestration), and/or bundles of ecosystem services (e.g. carbon sequestration plus biodiversity enhancement) (CCICED, 2007).

- Financing, which can come from different sources, including: the government effectively purchasing on behalf of a large number of beneficiaries. For example, public benefits purchased through Environmental Stewardship relating to landscape and biodiversity on behalf of English public private companies and individuals, downstream water users paying for watershed management on upstream land (Berry, 2006; CCICED, 2007).

Living Reviews in Landscape Research

http://www. livingreviews.org/lrlr-2011-2 
- Payment approaches, which can be classified into two main categories: output-based payments based directly on the delivery of ecosystem services (which can also be referred to as payments for results), and input-based payments for the adoption of particular land uses or land management practices that are expected to deliver additional ecosystem services and benefits (typical of many agri-environment subsidies).

Eco-compensation: Urgent needs for payment for ecosystem services in China have led to a wide range of policy and programme innovations, many under the broad heading of "ecocompensation", which is a term directly translated from the Chinese word shengtai buchang into English. The term was officially defined for the first time by the China Council for International Cooperation on Environment and Development in 2007, in a research project on PES. It stated that eco-compensation is a type of institutional arrangement to protect and sustainably use ecosystem services, and to adjust the distribution of costs and benefits between different actors and stakeholders, mainly through economic measures (CCICED, 2007). In other words, eco-compensation schemes aim to protect the ecological environment and improve relations between man and nature. It is a public regulation that aims to adjust relations between the stakeholders involved in ecological conservation on the basis of ecosystem service values, costs of ecological conservation, opportunity costs, and via government means and market schemes.

Internalisation of externalities is the key to eco-compensation. The theories of Pigovian Tax and Coase Transaction cost have a high policy significance for eco-compensation schemes. In the current selection of policy approaches concerning eco-compensation, various policy measures have different adaptive conditions and scope, and are subdivided according to the property rights and equity considerations of public goods concerning the issues of eco-compensation and the extent of ownership. If the marginal transaction fee via governmental adjustment is lower than the marginal transaction fee via voluntary consultation, it is better to take the approach of Pigovian Tax, e.g., by levying an eco-tax (fee) on the beneficiaries and destroyers of the eco-function, so as to solve the compensation issue.

The Chinese term "eco-compensation schemes" (buchang jizhi) appears to encompass both PES-like policies that involve direct payments from the government to individual and communitylevel suppliers of ecosystem services, as well as policies that develop frameworks of cooperation between various levels of government for the financing and sharing of costs of environmental protection and restoration. Compared with the term PES, eco-compensation emphasises the more institutional and political aspects of payment. This is because in China, apart from policy approaches concerning eco-compensation, direct payment in terms of monetary or in-kind to protectors of ecosystem services is currently often made by governments, and the market mechanism is not yet fully functional. The growing use and importance of eco-compensation within China's environmental policy framework is indicative of a greater emphasis not only on developing innovative market-based instruments for environmental policy, but also on resolving property rights and equity issues surrounding the use and protection of natural resources, which should be taken into consideration when creating eco-compensation schemes.

Although many Chinese policy and programme innovations relevant to PES fall under the broad heading of "eco-compensation", for international audiences and reference, we have chosen to use the umbrella term "Payment for Ecosystem Services (PES)" in this paper, to refer to the wide range of compensation made to the providers of ecosystem services. These payment schemes are currently being shaped in China, and are often at different stages of development - ranging from one-off payments between the beneficiaries and providers of ecosystem services to cap-and-trade markets (CCICED, 2007). 
Table 1: Ecosystem services and their constituents (MEA, 2003).

\begin{tabular}{|c|c|c|c|c|}
\hline Service & $\begin{array}{l}\text { Provisioning } \\
\text { Services }\end{array}$ & $\begin{array}{l}\text { Regulating } \\
\text { Services }\end{array}$ & $\begin{array}{l}\text { Cultural } \\
\text { Services }\end{array}$ & $\begin{array}{l}\text { Supporting } \\
\text { Services }\end{array}$ \\
\hline Explanation & $\begin{array}{l}\text { Products obtained } \\
\text { from ecosystems }\end{array}$ & $\begin{array}{l}\text { Benefits obtained } \\
\text { from regulating } \\
\text { ecosystem pro- } \\
\text { cesses }\end{array}$ & $\begin{array}{l}\text { Non-material } \\
\text { benefits obtained } \\
\text { from ecosystems }\end{array}$ & $\begin{array}{l}\text { Services necessary } \\
\text { for the produc- } \\
\text { tion of all other } \\
\text { ecosystem ser- } \\
\text { vices }\end{array}$ \\
\hline Sub-category & $\begin{array}{l}\text { - Food } \\
\text { - Fresh water } \\
\text { - Fuel wood } \\
\text { - Fibre } \\
\text { - Biochemicals } \\
\text { - Genetic re- } \\
\text { sources }\end{array}$ & $\begin{array}{l}\text { - Climate regula- } \\
\text { tion } \\
\text { - Disease regula- } \\
\text { tion } \\
\text { - Water regula- } \\
\text { tion } \\
\text { - Water purifica- } \\
\text { tion }\end{array}$ & $\begin{array}{l}\text { - Spiritual and } \\
\text { religious } \\
\text { - Recreation and } \\
\text { ecotourism } \\
\text { - Aesthetic } \\
\text { - Inspirational } \\
\text { - Educational } \\
\text { - Sense of place } \\
\text { - Cultural her- } \\
\text { itage }\end{array}$ & $\begin{array}{l}\text { - Soil formation } \\
\text { - Nutrient cy- } \\
\text { cling } \\
\text { - Primary pro- } \\
\text { duction }\end{array}$ \\
\hline
\end{tabular}

\section{Major components of PES schemes in China}

The eco-compensation scheme comprises three key components: responsibility scheme, compensation criteria and compensation methods. The responsibility scheme defines the identities of and the responsibilities to be borne by the interested parties in the eco-compensation scheme. The responsibilities borne by the interested parties may be defined following the property right system and the PPP (Polluter Pays Principle), UPP (User Pays Principle) and BPP (Beneficiary Pays Principle) in addition to the specific requirements of the applicable laws (CCICED, 2007).

The compensation criteria may either be identified based on the evaluation and calculation of the cost of environmental treatment (i.e. input in environmental protection) (Bai et al., 2008) and the loss caused to the ecological environment (the value of ecological services) (CCICED, 2007) or, as another option, through gaming and negotiations between both interested parties ( $\mathrm{Yu}$ and Ren, 2007).

The methods and approaches of compensation may be defined in accordance with many systems. However, the key factors involved therein are the compensation subjects and operational schemes. Based on the difference between the subject and the operational schemes of such compensation, eco-compensation may fall into two major categories, i.e., government compensation and market compensation (Bennett, 2009; Yin, 2009).

\subsection{Basic financial principles for PES schemes}

The principle parts of PES have been identified in accordance with the responsibilities and roles of the stakeholders involving in ecological conservation or damage. The following principles have been applied for PES in China (CCICED, 2007):

Living Reviews in Landscape Research

http://www. livingreviews.org/lrlr-2011-2 
- Damager Pays Principle (DPP): Here the damager should take responsibility for the negative impact of his activities on the ecosystem and pay for the rehabilitation of damaged ecosystems.

- User Pays Principle (UPP): This refers to users of environmental resources having to compensate the state or public representatives for using scarce resources due to their public ownership. The principle could be embodied in other ecological management fields at different scales, such as the taxation of individuals for arable land occupation, cutting trees and non-wood resources, mineral resource exploration; the enterprises should pay resource use fees after obtaining permission for use.

- Beneficiary Pays Principle (BPP): The beneficiary should pay the provider for ecological services at upstream and downstream locations. For the majority of ecosystem services that are "public goods", the establishment of PES requires governmental support. The government should take great pains to protect natural reserves that play an important role in the ecological security of the country, such as upstream, wind-break and sand-fixing areas, flood regulation areas, etc. However, BPP is broader in coverage than the UPP principle in the sense that, in some cases, benefits do not need to be derived from the use of resources; for instance, benefits gained could be clear air and landscape amenities generated due to ecosystem conservation by other individuals.

- Compensation to the protectors: Those groups and individuals who contribute to ecological construction should be compensated according to their investment and opportunity costs, the benefits provided by ES, beneficiaries' gains and the rehabilitation cost of damage.

- Property rights: Within the context of the mainstream conceptual basis for PES, i.e. Coasean economics, eco-compensation in fact attempts to reduce transaction costs by allocating property rights and establishing bargaining processes between those who provide the services and those who are willing to maintain or enhance the provision of such services through a payment (i.e. buyers of services) (Muradian et al., 2010; Pascual et al., 2010). In the Chinese context, property rights are closely related to land use rights and the right to commercialise services generated from land resources, such as payment for the conversion of crop land into grass and forest to improve ecosystem services and functions.

\subsection{Determination of compensation standards}

Compensation standards could be determined in accordance with four values: investment by protectors and opportunity costs, beneficiaries' gains, rehabilitation costs of damage and the value of the ecosystem services.

- Direct investment and opportunity costs incurred by protectors: Protectors' investments in terms of human resources, materials and capita resources should be taken into consideration when devising compensation standards. In addition, the opportunity costs of protectors should also be considered. In theory, the sum of direct investment and opportunity costs should be the base-line for setting the standard (CCICED, 2007).

- Beneficiaries'gains: A positive externality results when the benefits of conservation activities are not fully received by those involved in these activities (e.g. if beneficiaries have free use of ecological services and products without payment) (Li and Liu, 2010). In order to internalise such externality, beneficiaries should pay the full amount for ecological service providers. Thus, eco-compensation standards can be accounted for via the price and volume of market transactions. 
- Costs of rehabilitating damage: Resource development can cause biodiversity extinction, water loss, soil erosion and water pollution, and can affect ecosystem services such as soil and water conservation, climate regulation, etc. The costs incurred for pollution treatment and ecological restoration should therefore be paid.

- Value of ecosystem services: Evaluation of ecosystem services is used to calculate the value of soil and water conservation, climate regulation, biodiversity conservation, landscape beauty, etc. Many studies on the evaluation method have been carried out both in China and abroad. However, due to lack of standards for indicator selection and the valuation of the services, as well as the fact that ecosystem service values are much higher than compensation capacity, the evaluation results could only be considered as theoretical ceiling values when setting compensation standards (CCICED, 2007).

A practical standard could be determined through negotiation amongst stakeholders and in accordance with the real situation in the country and its regions, for instance, levels of economic development and ecological deterioration, and dynamic adjustment is required that takes into account ecological conservation and socio-economic development.

\subsection{Approach for PES}

According to the compensation methods, major approaches can be divided into compensation in cash, compensation in kind, compensation via appropriate policies and compensation via appropriate technologies and knowledge (Zhen et al., 2010; Li et al., 2011). Implementation bodies and their operational schemes are key to determining the chief characters of compensation methods, which can generally be categorised into two types: government compensation and market compensation.

- Government compensation: The government compensation scheme is currently the most important and easily implementable type in China. The government identifies who should be compensated and how much should be paid by taking the provision and protection of ecosystem services into account. It aims to ensure national ecological security, social stability and regionally coordinated development, and adopts the financial subsidy, policy support, project implementation, taxation reform and talent input as the compensation methods. The government compensation scheme includes financial transfer payment, policy support with regional differences, ecological protection projects and an environmental taxation system.

- Market compensation: The objects of market compensation could be the property of the ecological and environmental elements, ecosystem services or the performance or quota of the environment pollution treatment. Pigou (1932) theorised that market schemes, such as taxes and subsidies, could be used to align private and social costs and benefits in a society more closely. In practice in China, the government usually provides subsidies to those who protect ecosystems, for instance, by providing subsidies to farmers for converting their land from farmland into grassland and forest. The specific amount of subsidies may be based on economic loss from farming products, e.g., total income from selling harvests from farmland. Meanwhile, taxes are collected from developers on the basis of the total turnover from selling the products, e.g. from mining activities.

Although it follows the same theoretical basis, eco-compensation in China is a broader concept than PES because it has a built-in penalty concept. The unique characteristics of PES in China are summarised as: (1) the government domination of PES with a focus on institutional and policy aspects to determine compensation schemes; (2) a lack of a real marketing mechanism due to low marketisation, and externality cannot be totally solved by pure market instruments; (3) top-down approach of implementing PES; and (4) adoption of the penalty concept by setting, for instance, the "damager pays principle," and so on.

Living Reviews in Landscape Research

http://www. livingreviews.org/lrlr-2011-2 


\section{The rapid rise of $\mathrm{PES}$ in China}

\subsection{Major PES programmes in China}

The Chinese government has been experimenting tentatively with PES programmes for decades. In the early 1980s, the Ministry of Water Resources began to directly contract out fragile lands in some small watersheds to households for management, though with limited success (Liu, 2005). These initiatives have been embodied in the Water and Soil Conservation Act of the P.R.C. (1991), one of the first pieces of legislation passed to introduce market schemes into watershed management. It allows some small watersheds to be auctioned or leased to farmers or other private investors for development, with the lessee being obligated to protect against soil erosion and degradation. Since 1999, there have been a growing number of programmes that, in line with international trends, are increasingly utilising Payments for Ecosystem Services (PES) schemes. Several initiatives have been carried out successfully at national, regional and local levels. One example is the flagship Sloping Land Conversion Programme (SCLP - tuigeng huanlin huancao), which, for example, is arguably a PES programme (Wunder, 2005; Pagiola and Platais, 2007; Engel et al., 2008; Bennett, 2008). Table 2 summarises the major eco-compensation programmes that have been realised in China in recent years, and their magnitude.

Table 2: Major PES programmes in China (Bennett, 2009; Yin, 2009).

\begin{tabular}{|c|c|c|}
\hline Target & Program / Policy & Size \\
\hline \multirow[t]{2}{*}{$\begin{array}{l}\text { Water Quality } \\
\text { \& Quantity }\end{array}$} & $\begin{array}{l}\text { Watershed Eco- } \\
\text { compensation Pro- } \\
\text { grammes }\end{array}$ & $\begin{array}{l}\text { Total budget of RMB } 14.6+\text { billion, RMB } 703+\text { mil- } \\
\text { lion already spent, plus annual payments of RMB } \\
288+\text { million. }\end{array}$ \\
\hline & $\begin{array}{l}\text { Water Use Rights } \\
\text { Transfers }\end{array}$ & $\begin{array}{l}\text { Total estimated project costs of RMB } 2.777 \text { billion, } \\
\text { RMB } 1.149+\text { billion invested so far. }\end{array}$ \\
\hline \multirow[t]{4}{*}{ Forest-related } & $\begin{array}{l}\text { Sloping Land Con- } \\
\text { version Programme } \\
(\mathrm{SLCP})\end{array}$ & $\begin{array}{l}\text { Total budget of RMB } 337 \text { billion (of which RMB } \\
130.1 \text { billion has been spent from } 2000 \text { to } 2006 \text { ). } 139 \\
\text { million mu ( } 9.27 \text { million ha) of cropland enrolled } \\
\text { and } 205 \mathrm{million} \mathrm{mu} \text { ( } 13.67 \text { million ha) of wasteland } \\
\text { afforested. }\end{array}$ \\
\hline & $\begin{array}{l}\text { Central Government } \\
\text { Forest Ecosystem Com- } \\
\text { pensation Fund (FECF) }\end{array}$ & $\begin{array}{l}\text { A total of } 1.578 \text { billion mu ( } 105.2 \text { million ha) of na- } \\
\text { tional level key public benefit forest area enrolled } \\
\text { by the end of } 2007 \text {. Cumulative total investment of } \\
\text { RMB } 13.34 \text { billion by the end of } 2007 \text { (RMB } 3.34 \\
\text { billion in } 2007 \text { alone). }\end{array}$ \\
\hline & $\begin{array}{l}\text { Provincial-Level FECF } \\
\text { (complementary to cen- } \\
\text { tral government FECF) }\end{array}$ & $\begin{array}{l}\text { Apart from national key public benefit forest area, } \\
1.15 \text { billion mu ( } 76.7 \text { million ha) of provincial-level } \\
\text { public benefit forest area enrolled by the end of } \\
\text { 2007. Subsidies of RMB } 1.2 \text { billion in } 2006 \text {. }\end{array}$ \\
\hline & $\begin{array}{l}\text { Natural Forest Pro- } \\
\text { tection Programme } \\
(\mathrm{NFPP})\end{array}$ & $\begin{array}{l}\text { Total targeted forest area of } 1.023 \text { billion mu ( } 68.2 \\
\text { million ha), of which } 846 \text { million mu ( } 56.4 \text { million } \\
\text { ha) is designated as natural forest area. Total bud- } \\
\text { get for } 2000-2010 \text { is RMB } 96.2 \text { billion, of which the } \\
\text { central government will provide RMB } 78.4 \text { billion. }\end{array}$ \\
\hline
\end{tabular}


Table 2 - Continued

\begin{tabular}{|c|c|c|}
\hline Target & Program / Policy & Size \\
\hline & $\begin{array}{l}\text { "Three-Norths" Shelter- } \\
\text { belt Programme }\end{array}$ & $\begin{array}{l}\text { Completed afforesting } 367 \text { million mu ( } 24.47 \text { million } \\
\text { ha), and controls desertification on over } 450 \text { million } \\
\text { mu ( } 30 \text { million ha) and soil erosion on } 300 \text { million } \\
\text { mu ( } 20 \text { million ha) of land. Total estimated bud- } \\
\text { get for the current period of the programme (2001- } \\
2010) \text { is RMB } 35 \text { billion, of which RMB } 25 \text { billion } \\
\text { will be from the central government. }\end{array}$ \\
\hline & $\begin{array}{l}\text { Beijing-Tianjin Sand- } \\
\text { storm Source Control } \\
\text { Programme }\end{array}$ & $\begin{array}{l}\text { Total programme budget is RMB } 50 \text { billion, of } \\
\text { which Beijing is to invest RMB } 3.9 \text { billion. By the } \\
\text { end of } 2007,47 \text { million mu ( } 3.13 \text { million ha) of land } \\
\text { had been afforested, and total expenditures were } \\
\text { RMB } 19.9 \text { billion. }\end{array}$ \\
\hline & $\begin{array}{l}\text { Forest Vegetation } \\
\text { Restoration Fee }\end{array}$ & RMB 8.044 billion from 2003 to 2005 . \\
\hline \multirow[t]{3}{*}{ Soil erosion } & $\begin{array}{l}\text { "Four Wastelands" pol- } \\
\text { icy }(4 \mathrm{~W})\end{array}$ & $\begin{array}{l}\text { The size of the programme is likely to be huge both } \\
\text { in terms of land area and revenue generated for lo- } \\
\text { cal governments and participating farmers, as well } \\
\text { as in terms of imputed labour costs of soil erosion } \\
\text { prevention. }\end{array}$ \\
\hline & $\begin{array}{l}\text { Soil Erosion Control } \\
\text { Fees and Soil and Water } \\
\text { Conservation Instal- } \\
\text { lation Compensation } \\
\text { Payments }\end{array}$ & $\begin{array}{l}\text { No information available, although probably huge in } \\
\text { terms of revenue generated and land area involved, } \\
\text { since this policy encompasses the whole of China. }\end{array}$ \\
\hline & $\begin{array}{l}\text { Yangtze River Upper } \\
\text { Watershed Water and } \\
\text { Soil Conservation and } \\
\text { Key Prevention Pro- } \\
\text { gramme }\end{array}$ & $\begin{array}{l}\text { As of } 2004 \text {, more than RMB } 15.929 \text { billion spent for } \\
\text { management of soil erosion on over } 8 \text { million ha. }\end{array}$ \\
\hline \multirow[t]{3}{*}{$\begin{array}{l}\text { Eco- } \\
\text { agricultural }\end{array}$} & $\begin{array}{l}\text { National Green and Or- } \\
\text { ganic Food Certification } \\
\text { System }\end{array}$ & $\begin{array}{l}\text { Large and growing, though exact numbers are not } \\
\text { readily available. }\end{array}$ \\
\hline & $\begin{array}{l}\text { Dalian City, Liaoning } \\
\text { Province, Green Agri- } \\
\text { culture Support Subsidy }\end{array}$ & $\begin{array}{l}\text { No number available on the programme's total bud- } \\
\text { get or the number of farmers who have benefited } \\
\text { from these subsidies. }\end{array}$ \\
\hline & $\begin{array}{l}\text { Shanghai Organic Fer- } \\
\text { tiliser Subsidy }\end{array}$ & $\begin{array}{l}\text { The size of the programme has expanded from use } \\
\text { of } 15,000 \text { tons of organic fertiliser on } 100,000 \mathrm{mu} \\
(6,667 \mathrm{ha}) \text { in } 2004 \text {, to } 120,000 \text { tons of organic fer- } \\
\text { tiliser on } 600,000 \mathrm{mu}(40,000 \text { ha) in } 2006 \text {. From } \\
2004 \text { to } 2006 \text {, a total of RMB } 56.25 \text { million was } \\
\text { spent in subsidies. }\end{array}$ \\
\hline
\end{tabular}


Table 2 - Continued

\begin{tabular}{|c|c|c|}
\hline Target & Program / Policy & Size \\
\hline & $\begin{array}{l}\text { Beijing Organic Fer- } \\
\text { tiliser Subsidy and Safe } \\
\text { Pesticides Subsidy }\end{array}$ & $\begin{array}{l}\text { RMB } 20 \text { million invested in } 2007 \text { to subsidise the } \\
\text { use of } 75,000 \text { tons of organic fertiliser used on } \\
200,000 \mathrm{mu}(13,333 \mathrm{ha}) \text { of grain fields in } 13 \text { coun- } \\
\text { ties in Beijing. }\end{array}$ \\
\hline & $\begin{array}{l}\text { National VAT Tax Ex- } \\
\text { emption for Organic } \\
\text { Fertiliser Use }\end{array}$ & $\begin{array}{l}\text { No numbers are available on the size of total tax } \\
\text { exemptions. }\end{array}$ \\
\hline & $\begin{array}{l}\text { Rural Biogas Develop- } \\
\text { ment }\end{array}$ & $\begin{array}{l}\text { Central government investments of RMB } 12+\text { bil- } \\
\text { lion from } 2003 \text { to } 2008 \text {. Provincial and local gov- } \\
\text { ernment investments of RMB } 1.5 \text { billion in } 2006 \\
\text { alone. Programme activities from } 2004 \text { to } 2008 \text { en- } \\
\text { compassed counties and } 98,600 \text { villages, with } 10 \\
\text { provinces issuing complementary policies. A cumu- } \\
\text { lative total of } 26.23 \text { million household biogas stoves } \\
\text { installed by the end of } 2007 \text {. The programme aims } \\
\text { to have a total of } 40 \text { million household stoves in- } \\
\text { stalled by the end of } 2010 \text {. }\end{array}$ \\
\hline & $\begin{array}{l}\text { Promoting Conservation } \\
\text { Tillage }\end{array}$ & $\begin{array}{l}\text { Central government investment of RMB } 170 \text { mil- } \\
\text { lion from } 2002 \text { to } 2007 \text {, with matching local govern- } \\
\text { ment investments of RMB } 1.78 \text { billion. Enrolment } \\
\text { of } 30.62 \text { million mu ( } 2.04 \text { million ha) of conservation } \\
\text { tillage area, and almost } 100 \text { million mu ( } 6.67 \text { mil- } \\
\text { lion ha) of no-tillage area. Project encompasses } 15 \\
\text { northern provinces. }\end{array}$ \\
\hline \multirow[t]{3}{*}{ Carbon } & $\begin{array}{l}\text { Clean Development } \\
\text { Mechanism }\end{array}$ & $\begin{array}{l}\text { China hosts } 22 \text { per cent of registered CDM projects } \\
\text { and supplied } 73 \text { per cent of global CDM credits in } \\
2007 ; 725 \text { million tons CDE. }\end{array}$ \\
\hline & $\begin{array}{l}\text { Voluntary Carbon Mar- } \\
\text { ket }\end{array}$ & $\begin{array}{l}\text { The Asia-Pacific region (China data N/A) supplied } \\
39 \text { per cent, or } 16.4 \mathrm{MtCO}_{2} \text { e of global VERs. }\end{array}$ \\
\hline & China Green Fund & $\begin{array}{l}\text { RMB } 300 \text { million. } 1.05 \text { million } \mathrm{mu}(70,000 \mathrm{ha}) \text { of } \\
\text { area for afforestation. }\end{array}$ \\
\hline $\begin{array}{l}\text { Emissions } \\
\text { trading }\end{array}$ & $\begin{array}{l}\text { Ongoing Piloting of } \\
\mathrm{SO}_{2} \text { and COD Emis- } \\
\text { sions Permit System } \\
\text { and Emissions Trading }\end{array}$ & $\begin{array}{l}\text { Transactions of } 970 \text { tons/year of COD, } 28,500+ \\
\text { tons plus } 1,007 \text { tons/year of } \mathrm{SO}_{2} \text { (contract lengths } \\
\text { unknown). RMB } 52.81+\text { million in transactions. } \\
\text { More than RMB } 9.3 \text { million in government pilot } \\
\text { support funding. }\end{array}$ \\
\hline Other & $\begin{array}{l}\text { Government Green Pro- } \\
\text { curement }\end{array}$ & $\begin{array}{l}\text { Huge potential market size. In } 2006 \text {, total govern- } \\
\text { ment procurement was estimated to be over RMB } \\
300 \text { billion. }\end{array}$ \\
\hline
\end{tabular}


As shown in Table 2, subsidies are part of eco-compensation instruments in China. According to Pigou (1932), market mechanisms such as taxes and subsidies, could be used to align private and social costs and benefits in a society more closely. Specifically, taxing or subsidising an individual by exactly the amount of the positive/negative externality they produce by a given activity "internalises" the externality (i.e. the full social cost and benefit of the activity are also the individual's private cost and benefit), so that the individual's private decisions reflect socially optimal decisions. Thus, if a damager is taxed by exactly the amount of damage he creates, he would chose production and damage levels that are socially optimal. If a person who protects an important ecosystem is subsidised by exactly the amount of public benefits created by the ecosystem, the individual's private decisions would also be socially optimal. As such, the government should make use of such "Pigouvian Taxes" when the private and social environmental costs and benefits of an activity diverge.

As indicated above, most of the PES programmes in China are targeted to improve water quality and quantity, to control soil erosion, and promote eco-agriculture production. The watershed PES programme aims to ensure watershed ecological security and the sustainable use of water resources. It is useful in dealing with the ecological and economic relationship between upstream and downstream locations to promote the economic development and environmental protection of upper reaches and to realise the sustainable development of the entire watershed. In developing countries, several billion dollars are spent on watershed payments. The watershed compensations in China are currently being carried out at three levels. The first is the national project to protect the eco-environment of rivers in western China. The second is the trans-watershed water rights trading and fiscal transfer project, dominated by the government of Zhejiang province. The third is the watershed compensation system created by Fujian provincial government of southern China. Unlike international experience of market-based compensation for watershed (CCICED, 2007), market-based compensations are scattered in some areas in a quasi-market or semi-market status. The free trade market has not yet formed in China, but is foreseen as an effective means of compensation for watershed.

The eco-agricultural programme was established to promote the adaptation of organic production and sustainable resource management activities. The Chinese government provides subsidies for the use of organic fertilisers and bio-fuel energy, and promotes conservation tillage techniques. Meanwhile, a national green and organic food certification system has been widely implemented in China. These measures have contributed considerably to the improvement of ecosystem services, such as soil and water conservation, emissions reduction and water purification.

The main goal of SLCP is to reduce soil erosion and desertification, and to increase China's forest coverage by retiring steeply sloping and marginal lands from agricultural production. Available data indicates that soil erosion affects roughly 360 million hectares of land in China, some $38 \%$ of its total area, more than three times the world average (Huang et al., 1999; World Bank, 2001; SFA, 2003). The programme covers 25 provinces. The forest area of SLCP implementation increased by $22.9 \times 10^{6}$ ha from 1995 to 2005 , including $9.0 \times 10^{6}$ ha of afforested land converted from farmland, $12.6 \times 10^{6}$ ha of waste hills and unreclaimed lands suitable for forestation and $1.3 \times 10^{6}$ ha of mountain areas sealed for forestation.

Figure 1 presents a graphical illustration of converted land area under SLCP by year. During the pilot phase, an average of 408,000 hectares of cropland was converted per year. Upon full-scale implantation beginning in 2002, however, this jumped to 2.9 million hectares per year, a more than six-fold increase. The number of enrolled counties also rose significantly, by $374 \%$, between the end of 2001 and the end of 2002 (Bennett, 2008).

The total investment in this programme hit the 103 billion RMB mark by the end of 2005 . SLCP mandates that farmers who participated in land retirement and conversion be compensated. It stipulates that farmers who convert degraded and steep sloping cropland into either "ecological protective forests" (defined by the State Forestry Administration as timber-producing forests), or

Living Reviews in Landscape Research

http: //www. livingreviews.org/lrlr-2011-2 


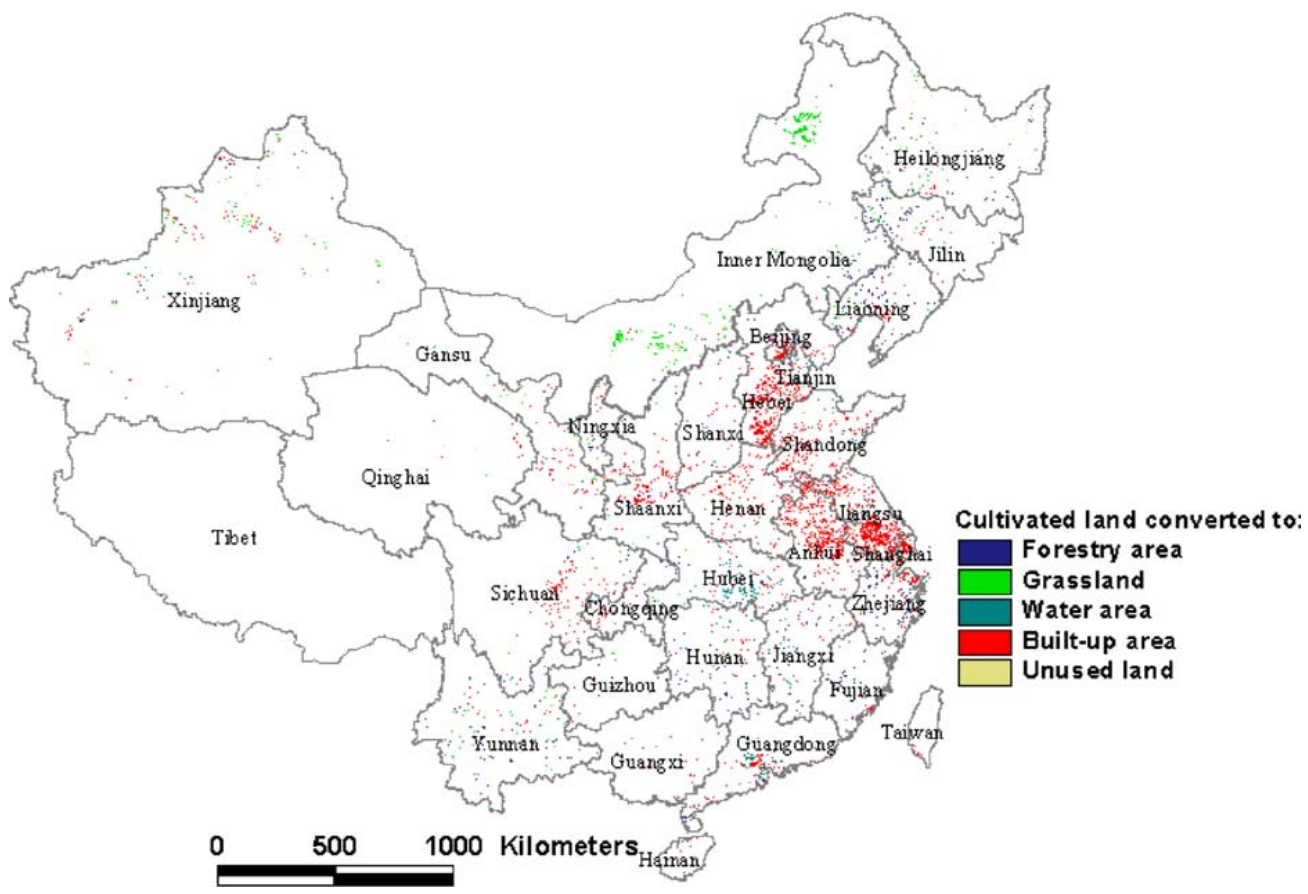

Figure 1: Distribution of land converted from cultivated land to other uses, 1986 to 2000 (Deng et al., 2006)

"economic forests" (orchards or plantations of trees with medicinal value) will be compensated with an annual in-kind subsidy of grain, a cash subsidy and free saplings at the beginning of the planting period. The grain subsidy is set at $2,250 \mathrm{~kg} / \mathrm{ha}$ in the Yangtze River Basin and $1,500 \mathrm{~kg} / \mathrm{ha}$ in the Yellow River Basin. The cash subsidy is $300 \mathrm{RMB} /$ ha per year. Both grain and cash subsidies are for 8 years if ecological forests are planted and for 5 years if economic forests are planted (in the more recent policy, the 8-year and 5-year compensation period can be extended another round, but with half the payment). However, payment for land converted may often be small and variable compared to household income. For instance, research conducted in southern China revealed that annual payments received by farmer households comprise a small share of the total household income (i.e. around 2\%, see Zhen et al., 2006, 2010; Li et al., 2011) because these households and communities already have the incentive to protect and improve their local environment - this is considered a successful aspect of the programme. Our survey has shown (Figure 2) that most farmers were Willing To Pay (WTP) between 750 and 1,125 RMB/year, and the consensus rate decreases steadily with increasing bid value, and an average annual per household payment was $956 \mathrm{RMB} /$ ha. Even so, whether farmers would reclaim converted land into agriculturally productive land as soon as the programme and associated payments are terminated is still a challenge for policy-makers to achieve ecosystem conservation objectives. Other case studies (Uchida et al., 2005; Xu et al., 2010) have indicated that those households that originally did not wish to participate in the programme, or who are not compensated adequately for their opportunity costs of participation, will simply return land to cultivation at the end of the subsidy period. Results from the survey indicate that this is not a small share of participants, although some farmers are overcompensated. 


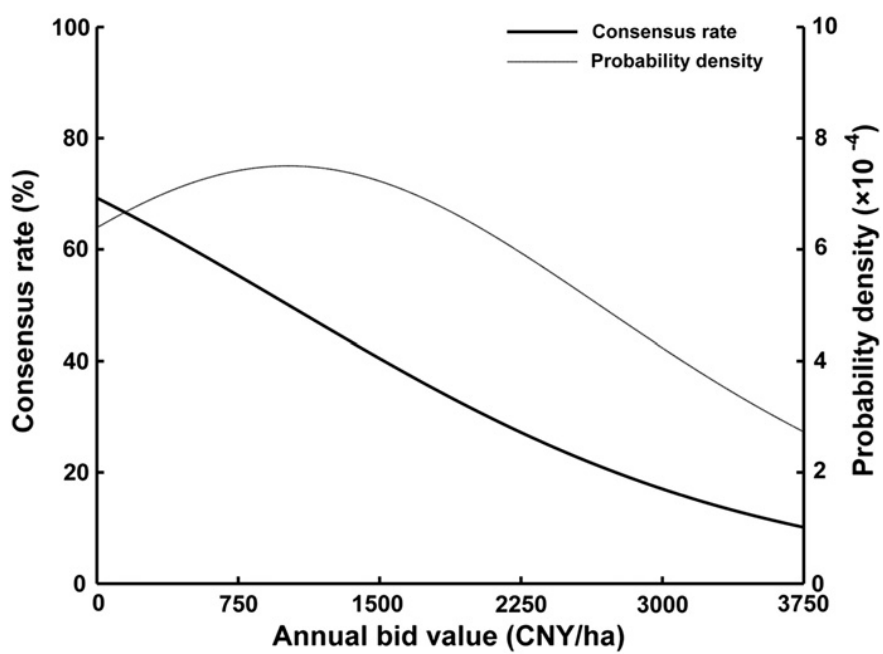

Figure 2: Functional relationships between bid amount, consensus rate and probability density of WTP (from Zhen et al., 2011).

\subsection{Pilot studies on PES implementation in China}

As a response to the 11th Five-year Guidelines, China's Ministry of Environmental Protection (MEP) issued Guiding Opinions on the Development of Eco-compensation Pilot Work (MEP, 2007). In this, the MEP detailed four main areas of focus for the development of PES pilots: watersheds, key ecological function areas, mineral development areas and nature reserves. Based on the research progress and urgent needs for decision-making, the China Council for International Cooperation on Environment and Development (CCICED) established the Task Force on PES and policy research, with the aim of establishing national strategies and sectoral policies for PES, and making concrete proposals and recommendations to the government. Table 3 lists the major findings from the pilot studies, which includes subject to pay, approach for payment, capital sources and standards for payment.

It is concluded from this programme that local governments are responsible for establishing PES of urban water sources and local small watersheds within their administrative boundaries and that they should cooperate with the central government to establish PES for cross-boundary medium-sized watersheds. With the exception of the further improvement of existing ecological protection programmes, an urgent issue is to establish long-term effective schemes for PES. Meanwhile, compensation standards could be determined following the four kinds of values: investments by protectors and opportunity costs, beneficiaries' gains, rehabilitation costs of damage and ecosystem services. According to Rule of Thumb, the sum of direct investment and opportunity cost should be the base-line for determining the standard, while the value of ecosystem services is considered to be the theoretical ceiling values for compensation. 
Table 3: Findings from the pilot study in selected key fields for PES in China.

\begin{tabular}{|c|c|c|c|c|}
\hline PES Items & Watershed & $\begin{array}{l}\text { Mineral } \\
\text { resource }\end{array}$ & Forest & Nature reserve \\
\hline $\begin{array}{l}\text { Whom to pay } \\
\text { (Subject) }\end{array}$ & $\begin{array}{l}\text { Water users } \\
\text { Pollutants }\end{array}$ & $\begin{array}{l}\text { Government pays } \\
\text { for rehabilitation } \\
\text { of abandoned } \\
\text { mines } \\
\text { Mine owners }\end{array}$ & $\begin{array}{l}\text { Beneficiaries } \\
\text { Damagers of for- } \\
\text { est resources }\end{array}$ & $\begin{array}{l}\text { Government } \\
\text { Beneficiaries }\end{array}$ \\
\hline $\begin{array}{l}\text { How to pay } \\
\text { (Approach) }\end{array}$ & $\begin{array}{l}\text { Government sets } \\
\text { up a platform for } \\
\text { stakeholder ne- } \\
\text { gotiation. Public } \\
\text { payment, one-to- } \\
\text { one trading, in } \\
\text { kind and cash, } \\
\text { training, eco- } \\
\text { certification }\end{array}$ & $\begin{array}{l}\text { Capital compen- } \\
\text { sation, rehabili- } \\
\text { tation project }\end{array}$ & $\begin{array}{l}\text { Fiscal transfer, } \\
\text { tax reduction, } \\
\text { immigration } \\
\text { subsidy, market } \\
\text { trading, ecologi- } \\
\text { cal marks }\end{array}$ & $\begin{array}{l}\text { Government pur- } \\
\text { chases, fiscal } \\
\text { transfer, policy } \\
\text { (tax mitigation, } \\
\text { subsidy), project, } \\
\text { international } \\
\text { support }\end{array}$ \\
\hline $\begin{array}{l}\text { Where is the } \\
\text { money from } \\
\text { (Capital } \\
\text { sources) }\end{array}$ & $\begin{array}{l}\text { Tax, eco- com- } \\
\text { pensation funds, } \\
\text { preferential } \\
\text { credit, over- } \\
\text { seas capital, pro- } \\
\text { gramme aid }\end{array}$ & $\begin{array}{l}\text { Fiscal transfer, } \\
\text { eco- compensa- } \\
\text { tion funds from } \\
\text { the owner, mines } \\
\text { compensation } \\
\text { bond }\end{array}$ & $\begin{array}{l}\text { Compensation } \\
\text { funds, earmarked } \\
\text { funds for eco- } \\
\text { conservation, } \\
\text { ecological taxa- } \\
\text { tion }\end{array}$ & $\begin{array}{l}\text { Fiscal transfer, } \\
\text { multiple financ- } \\
\text { ing channels } \\
\text { (NGOs, volun- } \\
\text { teers) }\end{array}$ \\
\hline $\begin{array}{l}\text { How much } \\
\text { is to be paid } \\
\text { ( } \text { Standard) }\end{array}$ & $\begin{array}{l}\text { Direct invest- } \\
\text { ment and op- } \\
\text { portunity cost } \\
\text { upstream, cost } \\
\text { of newly con- } \\
\text { structed infras- } \\
\text { tructure, water } \\
\text { consumed down- } \\
\text { stream }\end{array}$ & $\begin{array}{l}\text { Value of ecosys- } \\
\text { tem damage, cost } \\
\text { of environment } \\
\text { rehabilitation }\end{array}$ & $\begin{array}{l}\text { Direct expense } \\
\text { of re-plantation, } \\
\text { opportunity costs } \\
\text { for forests pro- } \\
\text { tection and ben- } \\
\text { efits gained from } \\
\text { forest ES }\end{array}$ & $\begin{array}{l}\text { Value of ES, pro- } \\
\text { tection costs, } \\
\text { losses from ES } \\
\text { degradation }\end{array}$ \\
\hline
\end{tabular}




\section{$5 \quad$ Future perspectives}

Economic developments in China have been rapid, and policy-makers still face numerous challenges in creating effective and financially sustainable policies for PES. To deal with such challenges, the following important relations shall be taken into consideration: 1) Relations between equity and efficiency in PES schemes. As addressed by Pascual et al. (2010), the relationship between equity and efficiency in PES emphasise the role of the institutional setting, social perceptions about economic fairness (or distributive justice of the payments), uncertainty and interactions between agents, including power relations. This is essential for Chinese eco-compensation, considering the centralised government system and existing close interrelations among the agencies. The central government should provide policy guidance, a legislative basis and financial support for local governments to establish PES schemes. It would also have to guide local governments in formulating, in the first place, country-wide and regional-wide, inter-watershed PES schemes. It is widely accepted that local governments are the main actors in formulating and implementing PES schemes. 2) Relations between the government and the market. Both the government and the market play an important role in establishing compensation schemes. However, China's policy-makers are still new to PES and market-based instruments in general. Based on the ecological conservation status and the market development in China, the government plays a key role in establishing PES schemes, including policy and law, and provides support for large-scale compensation. 3) Relations between PES and poverty alleviation. PES differentiates from poverty alleviation, and does not further the purpose of social equality and narrowing the gap between the rich and the poor (Li and Liu, 2010). Many assumed that PES will contribute to poverty reduction by making payments to poor land users, while others have warned of the potential dangers (Pagiola et al., 2005; Grieg-Gran et al., 2005; Wunder, 2008). However, PES schemes can be used to give rural dwellers a new social role as ecosystem service providers for ecosystems under stress. PES can thus serve to help them achieve these goals while financing the transition to more profitable and ecologically-friendly production systems. 4) Relations between "blood generating" and "blood transmitting". A "blood-generating" kind of compensation should be encouraged by initiating ecoconservation and capacity rising programmes, while a "blood-transmitting" kind of compensation could be applied for ordinary people. However, as far as the multifunctional role of agriculture is concerned (Van Huylenbroeck et al., 2007), once ordinary people, such as farmer households, receive compensation, they would be able to participate in production and trading activities to generate income for a substantial livelihood, which is important for the long-term conservation of ecosystem services. 5) Relations between integrated and sectoral platforms. An integrated PES platform dominated by the government would have to be established to ensure effective operation. However, various platforms should be encouraged at the local levels to explore various types of compensation. For instance, the private sector could have a potential role to play in PES. As a means to bring in the private sector, the government could start making a stepwise transition from fully public to public-private partnerships and private initiatives in a way that makes sense in the Chinese context. A legal framework will first need to be provided that will facilitate individual companies to make small PES deals.

\section{Acknowledgements}

This study was funded by the National Basic Research Programme of China (No. 2009CB421106), the Knowledge Innovation Programme of CAS (KZCX2-EW-306), Special Funds for Sino-EU Cooperation of MOST (0813) and the National Key Project of Science and Technical Supporting Programmes of China (No 2008BAK50B05).

Living Reviews in Landscape Research

http://www. livingreviews.org/lrlr-2011-2 


\section{References}

Bai, Y., Zeng, H., Wei, J.B., Zhang, W.J. and Zhao, H.W. (2008), "Optimization of ecological footprint model based on environmental pollution accounts: A case study in Pearl River Delta urban agglomeration", Chinese Journal of Applied Ecology, 19(8): 1789-1796. In Chinese with English abstract. (Cited on page 8.)

Bennett, M.T. (2008), "China's sloping land conversion program: Institutional innovation or business as usual?", Ecological Economics, 65(4): 699-711, [DOI]. (Cited on pages 11 and 14.)

Bennett, M.T. (2009), "Markets for Ecosystem Services in China: An Exploration of China's 'Ecocompensation' and Other Market-Based Environmental Policies. A Report from Phase I Work on an Inventory of Initiatives for Payments and Markets for Ecosystem Services in China", Washington, DC (Forest Trends). Online version (accessed 9 June 2011):

http://forest-trends.org/publication_details.php?publicationID=2317. (Cited on pages 6,8 , and 11.)

Berry, R.J., ed. (2006), Environmental Stewardship: Critical Perspectives, Past and Present, London; New York (T\&T Clark). Google Books. (Cited on page 6.)

CCICED (2007), "Eco-Compensation Mechanism and Policies in China", Beijing (Science Press). Online version (accessed 21 June 2011):

http://tinyurl.com/68fdmzf. Full URL: http://www.caep.org.cn/english/paper/CCICEDTF-Summary-Report-on-Eco-compensation-Policy-in-China.pdf. (Cited on pages 5, 6, 7, 8, 9, 10, and 14.)

DEFRA (2010), "Payments for ecosystem services: A short introduction", London (Department for Environment, Food and Rural Affairs). URL (accessed 9 June 2011):

http://archive.defra.gov.uk/environment/policy/natural-environ/documents/ payments-ecosystem.pdf. (Cited on page 6.)

Deng, X.Z., Huang, J.K., Rozelle, S. and Uchida, E. (2006), "Cultivated land conversion and potential agricultural productivity in China", Land Use Policy, 23(4): 372-384, [DOI]. (Cited on page 15.)

Engel, S., Pagiola, S. and Wunder, S. (2008), "Designing payments for environmental services in theory and practice: An overview of the issues", Ecological Economics, 65: 663-674, [DOI]. (Cited on pages 5, 6, and 11.)

Grieg-Gran, M., Porras, I. and Wunder, S. (2005), "How can market mechanisms for forest environmental services help the poor? Preliminary lessons from Latin America", World Development, 33(9): 1511-1527, [DOI]. (Cited on page 18.)

Huang, J., Rozelle, S. and Rosegrant, M. (1999), "China's Food Economy to the Twenty-first Century: Supply, Demand, and Trade", Economic Development and Cultural Change, 47(4): 737-766, [DOI]. (Cited on page 14.)

Kumar, P. and Muradian, R., eds. (2009), Payment for Ecosystem Services, Transcripts of papers presented at a conference organized by International Society for Ecological Economics, held at New Delhi during December 2006, Ecological Economics and Human Well-being, New Delhi; New York (Oxford University Press). (Cited on page 6.)

Li, F., Li, W., Zhen, L., Huang, H., Wei, Y. and Inoue, N. (2011), "Estimating eco-compensation requirements for forest ecosystem conservation: A case study in Hainan province of Southern China", Outlook on Agriculture, 40(1): 51-57, [DOI]. (Cited on pages 10 and 15.) 
Li, W. and Liu, M. (2010), "Several strategic thoughts on China's eco-compensation mechanism", Resources Science, 32(5): 791-796. (Cited on pages 9 and 18.)

Liu, Z. (2005), "Retrospect and prospect on integrated management of soil conservation in small river basins", China Water Resources, 2005(19): 17-20. (Cited on page 11.)

MEA (2003), Ecosystems and Human Well-being: A Framework for Assessment, Millennium Ecosystem Assessment Series, Washington, DC (Island Press). Google Books. (Cited on pages 5, 6 , and 8.)

MEP (2007), "Guiding Opinions on the Development of Eco-compensation Pilot Work", MEP Issue, 130, Beijing (Ministry of Environmetal Protection of the PRC). (Cited on pages 5 and 16.)

Muradian, R., Corbera, E., Pascual, U., Kosoy, N. and May, P.H. (2010), "Reconciling theory and practice: an alternative conceptual framework for understanding payments for environmental services", Ecological Economics, 69: 1202-1208, [DOI]. (Cited on page 9.)

Pagiola, S. and Platais, G. (2007), "Payments for Environmental Services: From Theory to Practice", Washington, DC (World Bank). (Cited on pages 5 and 11.)

Pagiola, S., Arcenas, A. and Platais, G. (2005), "Can payments for environmental services help reduce poverty? An exploration of the issues and the evidence to date from Latin America", World Development, 33: 237-253, [DOI]. (Cited on page 18.)

Pascual, U., Muradian, R., Rodríguez, L.C. and Duraiappah, A. (2010), "Exploring the links between equity and efficiency in Payments for Environmental Services: a conceptual approach", Ecological Economics, 69(6): 1237-1244, [DOI]. (Cited on pages 9 and 18.)

Pigou, A.C. (1932), The Economics of Welfare, London (Macmillan), 4th edn. Google Books. Online version (accessed 10 June 2011):

http://www.econlib.org/library/NPDBooks/Pigou/pgEW.html. (Cited on pages 5, 10, and 14.)

SFA (2003), "Sloping Land Conversion Program Plan (2001-2010)", Beijing (State Forestry Administration). In Chinese. (Cited on page 14.)

State Council (2005), "Decision of the State Council Regarding Using the Scientific Development View to Strengthen Environmental Protection", no. 39, Beijing (State Council). (Cited on page 5.)

Sterner, T. (2003), Policy Instruments for Environmental and Natural Resource Management, Washington, DC (Resources for the Future). Google Books. (Cited on page 6.)

Uchida, E., Xu, J. and Rozelle, S. (2005), "Grain for green: cost-effectiveness and sustainability of China's conservation set-aside program", Land Economics, 81(2): 247-264, [DOI]. (Cited on page 15.)

Van Huylenbroeck, G., Vandermeulen, V., Mettepenningen, E. and Verspecht, A. (2007), "Multifunctionality of Agriculture: A Review of Definitions, Evidence and Instruments", Living Reviews in Landscape Research, 1(3). URL (accessed 9 June 2011):

http://www.livingreviews.org/lrlr-2007-3. (Cited on page 18.)

World Bank (2001), "China: Air, Land and Water. Environmental Priorities for a New Millennium", Washington, DC (World Bank). Online version (accessed 10 June 2011):

http://go.worldbank.org/SS60DE48X0. (Cited on page 14.)

Living Reviews in Landscape Research

http://www. livingreviews.org/lrlr-2011-2 
Wunder, S. (2005), "Payments for environmental services: some nuts and bolts", Occasional Paper, No. 42, Bogor, Indonesia (CIFOR). URL (accessed 10 June 2011): http://www.cifor.cgiar.org/nc/online-library/browse/view-publication/ publication/1760.html. (Cited on page 11.)

Wunder, S. (2008), "Payments for environmental services and poor: concepts and preliminary evidence", Environment and Development Economics, 13(3), [DOI]. (Cited on page 18.)

Xu, J., Tao, R., Xu, Z. and Bennett, M.T. (2010), "China's Sloping Land Conversion Program: Does Expansion Equal Success?", Land Economics, 86(2): 219-244. (Cited on page 15.)

Yin, R.S., ed. (2009), An Integrated Assessment of China's Ecological Restoration Programs, Dordrecht; New York (Springer), [DOI]. Google Books. (Cited on pages 8 and 11.)

Yu, H. and Ren, Y. (2007), "Theoretical bases of eco-compensation", Urban Environment $\&$ Urban Ecology, 20(2): 1-4. In Chinese with English abstract. (Cited on pages 5 and 8.)

Zhang, Q., Bennett, M.T., Kannan, K. and Jin, L., eds. (2010), Payments for Ecological Services and Eco-Compensation: Practices and Innovations in the People's Republic of China, Proceedings from the International Conference on Payments for Ecological Services, Ningxia Hui Autonomous Region, People's Republic of China, 6-7 September 2009, Mandaluyong City (Asian Development Bank). URL (accessed 21 June 2011):

http://tinyurl.com/64pkcty. Full URL: http://beta.adb.org/publications/paymentsecological-services-and-eco-compensation-practices-and-innovations-peoples-rep. (Cited on page 5.)

Zhen, L., Min, Q., Jin, Y. and Yang, G. (2006), "Socio-Economic Impact and Eco-compensation Mechanism in Natural Reserves of Hainan Province", Resources Science, 28(6): 10-19. (Cited on page 15.)

Zhen, L., Liu, X.L., Li, F., Wei, Y.J. and Koenig, H. (2010), "Consumption of ecosystem services and eco-compensation mechanism in ecological sensitive regions: progress and challenges", Resources Science, 32(5): 797-803. (Cited on pages 10 and 15.)

Zhen, L., Li, F., Huang, H., Dilly, O., Liu, J., Wei, Y. and Yang, L. (2011), "Households' willingness to reduce pollution threats in the Poyang Lake region, southern China", Journal of Geochemical Exploration, 110(1): 15-22, [DOI]. (Cited on page 16.) 